\title{
Corporate Civil Airlines Criminal Responsibility against Theft of Passengers Luggage in Terms of the Aspect of Criminal Law Indonesia
}

\author{
Benny Sumardiana \\ Aviation Law Expertise at Department of Criminal Law, Faculty of Law, \\ Universitas Negeri Semarang (UNNES), Indonesia \\ Email: bennysumardiana@mail.unnes.ac.id
}

\begin{abstract}
Air transportation has a place in the hearts of the people, As a major transportation. Airline offers a lot of facilities that can be enjoyed passengers. The facilities are all about comfort in flight And its land crew service facilities. But, among the various strengths there is one community concerns that's the theft was to passengers luggage, Loss of luggage or the contents of the luggage that missing. It is come to the attention of the public because so may cause adverse effect to airlines passengers. To this article will be discussed how the law aspect of airline responsibility over the phenomena.Corporate in this matter is an airline flight as the subject of a criminal act flight law make a different form of criminal responsibility with the individual criminal accountability. So, examined and discussed legal issues related to this is Reduction policy of criminal acts of flight in indonesia and Corporate civil airlines criminal responsibility Against theft passengers luggage In terms of the aspect of criminal law indonesiaWriting method of this legal research is a normative juridical research conducted by collecting primary, secondary and tertiary legal materials through literature study. The legal substance studied is Code No. 1 of 2009 About aviation and The Criminal Code. The legal material is then analyzed qualitatively and presented analytically descriptively.
\end{abstract}

Keywords—Aviation Law; Airline; Corporate Responsibility; Criminal Law

\section{INTRODUCTION}

In the current era, transportation can be carried out by land, sea and air. one of the transportation facilities that needs to be considered and very important role is air transport. Air transportation is an activity using an aircraft as a cargo or passenger transport vehicle in a trip or more than an airport to another airport or several domestic or foreign airports. (Fauzi, 2016: 142)

Flights in Indonesia continue to grow rapidly and become a favorite mode of transportation for the community. Airlines as providers of civil transport services continue to innovate to provide a sense of comfort and safety to the public as passengers or flight service users. These innovations include various sectors starting from ticket sales that switch to online services, airport service innovations such as counter check-in, boarding, as well as innovation in aviation, and innovation after the flight ends or when passengers arrive at the destination airport. These innovations were made to make Indonesian civil aviation a viable choice of transportation mode.

However, in the process of developing civil aviation various problems often arise, even some of them become major obstacles which sometimes lead to doubts about choosing this mode of transportation, the problems of which are:
a. Flight Late
b. Flight delay
c. Loss of passenger baggage

d. Passenger baggage damage

e. Unsatisfactory airline staff service

f. Flight accident

These problems until this day are difficult to resolve even though the happening case was officially reduced but often these problems arise by presenting huge losses to passengers. The focus in writing this time is the problem related to loss and damage to passenger baggage.

In flight, passengers have the right to carry their possessions, and airlines provide facilities for passengers to place their goods in two types of places, namely cabin and baggage. The cabin is interpreted as a space that is directly above the passenger seat that can be used to place passenger luggage, because the small volume of passengers not much can carry their goods to the cabin is usually limited to weight between $5-10 \mathrm{~kg}$ according to the policies of each airline. Baggage is a larger space than a cabin that is used to place passenger luggage with a capacity that is also greater, the weight of passenger goods that can be placed in the baggage also has a limit even though it is greater than $15-40 \mathrm{~kg}$ in accordance with the policies of each airline.

Baggage theft trends with the method of unloading, damaging, or even directly carrying whole passenger luggage is increasing. In 2018, a number of cases of theft or destruction appeared even some of them were directly caught on video and eventually viral on social media. The trends that occurs in 2018 is by stealing directly when entering luggage into the baggage of the aircraft, and the 
latest when picking up luggage on the conveyor belt there are non-passengers who have managed to enter the airport and take other passengers' baggage. As for destruction, viral video is when officers in charge of raising and lowering luggage carry out their work by throwing passenger baggage so that a lot of passenger luggage is damaged or even destroyed.

Regarding passenger baggage, this is a service provided by the airline for passengers. Managing passenger baggage is one thing that is inseparable from the major tasks carried out by the airline so that keeping the baggage of passengers is as important as maintaining the safety of the passengers themselves. So that the loss or damage that occurs to passenger baggage is the responsibility of the airline on a corporate basis.

Airlines in handling baggage often use the services of other parties to take care of passenger baggage. Other parties here may be subsidiaries or companies that are specifically involved in aircraft baggage handling. However, even though the airline directly retains responsibility because the airlines themselves choose the company and they also have to oversee how they work in handling passenger baggage. So, it is also their authority to provide an assessment if the company works well or not well, if it works badly or is known to make a mistake that can harm the airline passengers can replace it with a company that works better. So, it is not possible for airlines to throw responsibility to the companies they employ related to passenger baggage handling in the event of loss and damage that is detrimental to passengers because this is their full responsibility as a corporation.

The writing related to corporate responsibility for loss of passenger baggage and damage done by the division that manages passenger baggage is an important matter and has received much public attention. Along with the development of civil aviation that so attracts the attention of consumers, safety and comfort are the most important things to pay attention to, because that is why the author feels the need to discuss the topic in this legal article.

\section{RESEARCH METHOD}

Law writing scientificly cannot be separated from the right method of research so that it will produce thoughts that the level of truth can be accounted for. in legal research has many methods presented in accordance with the concept of writing or research that will be carried out. On writing the law on Corporate Criminal Liability for Civil Aviation Against Passenger Baggage Theft Judging from the Indonesian Criminal Law Aspect will use a type of normative or doctrinal legal research conducted by collecting primary, secondary and tertiary legal materials through literature studies.

The problem approach used in this legal research is as follows; First, the statutory approach, in this approach examines and examines legal material, the legal material reviewed here is Law No. 1 of 2009 concerning Aviation and the Criminal Code. The legal material is then analyzed qualitatively and presented in analytical descriptive, as well as other related legislation. Second, the conceptual approach, this approach is used to understand the abstract elements contained in the mind and historical approach, which is an approach used to know, understand and examine how the development of law and the background of the birth of a regulation. (Wirya, 2015: 8)

From the data obtained from the above process, it will then be analyzed and processed using a cross-site analysis model. This model will make it easier for researchers to uncover and map problems, relate one problem to another, and relate the research problem to the natural setting of the study as an external factor in the analysis of research data. Based on this pattern of analysis, it will be able to formulate and simultaneously verify the building of new information, methods and models in approaching similar problems with a higher level of scientific truth. (Adnyani, 2016: 50)

By the method, it neccessary need that writing can be accounted for so that the study will also be appropriate if applied to solve problems in the community related to criminal liability of airline companies for lost or damaged passenger baggage.

\section{RESULT AND DISCUSSION}

\section{A. Passenger Baggage Thievery Reviewed from Indonesian Criminal Law Aspect}

Civil air transportation or commonly referred to as civil aviation is certainly not free from the scope of legal science known as aviation law. Aviation law basically has its own meaning that is different from the air law both in terms of objects and all related processes. Aviation Law basically regulates flights made by aircraft that utilize air space as a crossing route with all accompanying things, both passengers in civil aviation, military and cargo transportation. The scope of aviation law also covers all flight processes, whether before flight (pre-flight), during flight (in-flight), or after a flight (post-flight). Problems that arise in flight related to passengers are objects of the aviation law itself, due to the wide scope of the legal object of flight from pre-flight, in-flight, and post-flight. Regarding the theft of passenger baggage, the damage can occur in all three flight processes, but what has often happened is during pre-flight and post-flight processes. It should be noted that one of the objectives of holding a flight is to realize safe, orderly and regularity, comfortable and economical flights (economy for company) (Nasution, 2007: 202-204). The purpose of the flight must include all flight periods both before the flight (pre-flight service), during flight (in-flight service), and after flight (post-flight service). If passengers who use flight services get improper service and result in violations of passenger rights that cause losses, the airline as a carrier must be responsible as mandated by the Flight Regulation.

The theft of passenger baggage is basically an act committed by an individual or a group, in the Criminal Code itself, the theft is regulated in article 362 which reads "Whoever takes something, completely or partially belongs to someone else, with the intention of owning the property against the right, convicted of theft, with a maximum jail term of five years or a maximum fine of $\mathrm{Rp}$. 
900 ", usually the airlines employ the ground handling employees who directly take care of passenger baggage working unprofessionally. The airline has actually tried to avoid theft of baggage by appealing to passengers not to carry valuables to be included in the passenger baggage, but the author feels that this effort is the only one part of the effort to simplify or ease the responsibilities inherent by the airlines. Because, if with a good supervision and professional baggage management staff, then it does not matter about any items carried by passengers and will remain in a safe condition. Therefore, theft of baggage or damage to baggage the author concludes is an illegal act by an airline.

In law, there are 3 (three) categories of Unlawful acts known as follows : (Fuady, 2002: 3)

a. Unlawful acts because of intent

b. Unlawful acts without Intention or omission

c. Unlawful acts due to negligence

If you see the meaning of the Unlawful acts above, then in the theft of baggage of civil aviation passengers, the fault of the airline is categorized as an unlawful act because of negligence. Failed here because the airline does not exercise good control over its employees who take care of passenger baggage, the weakness of supervision is what causes easy theft or damage to passenger baggage.

Even if seen from the 1929 Warsaw Convention in reviewing criminal acts of baggage theft, this aircraft uses the concept of presumption of liability. In the concept of the presumption of guilt, the airline company is responsible for the law, without being proven in advance by the airline company, but the responsibility of the airline company is limited. (Kizza, 1980: 1) The airline company's liability limit does not apply if the passenger have a prove that the airlines company or employees or agents or representatives who act for and on behalf of the airline company make a deliberate mistake (willfull missconduct), or the act that can be categorized as intentional.

\section{B. Corporate Criminal Responsibility of Civil Airlines}

Theft of passenger baggage is a big thing that requires immediate attention and handling. Especially to know in advance who is most responsible for the loss of passenger baggage. In fact, the security of passenger baggage is a fairly basic problem and easily becomes a concern for airline companies. Because only two forms of their security services for passengers are passenger security and the security of the passenger luggage itself.

According to E. Saefullah there are several fundamental problems in air transportation activities, namely (Wiradipradja, 2006: 23): First, in terms of regulation it is still not well organized. This problem runs from the systematic material of national legislation to the implementation stage in the field that still requires serious handling. Second, with the increasing number of national airlines, currently operating 565 aircraft including 390 jet aircraft, this situation is certainly encouraging because it will provide many choices for consumers. However, on the other hand a situation like this also creates misguided competition because every airline does not try to provide the best service but the competition is in the form of tariff war to get as many passengers as possible. As a result, to compensate for the reduced profits they make efficiency which unfortunately is also misguided so that it has a major impact on flight safety factors. Third, the era of globalization and liberalization, including in the field of aviation, is a necessity. Ironically, on the other side of the national aviation world we have not fully prepared to deal with it.

Regarding the theft of passenger baggage and their damage, there are a number of things that result in the occurrence or loss of passenger checked baggage due to flight, namely :

a. Defects of baggage or negligence of passengers

b. Loss of part or all of the passenger checked baggage

c. Forcing conditions, such as the risk of natural disasters, demonstrations and strikes.

d. Errors and omissions of the carrier.

Any of the above losses experienced by passengers in the form of legal issues is primarily the responsibility of the airline or carrier to the passengers and property owners both as parties to the transportation agreement and as consumers. There are no legal remedies that can be made to the problem. (Khairandy, 2006: 20)

The responsibility can be known from the obligations set out in the agreement or law, the obligation of the carrier is to carry out transportation where this obligation is binding since the passenger or sender repays the transportation fee. (Komar, 1994: 3).

Regarding the responsibilities of flights in Indonesia regulated in Code No. 1 of 2009 about Aviation which was created by the emergence of the Cape Town 2001 Convention which was largely adopted by Code No. 1 of 2009 about Aviation, which was a substitute for Code No. 15 of 1992 about Aviation.

However, in relation to airline corporate responsibility, Code No. 1 of 2009 about Aviation actually provides protection to corporations in relation to actions that harm the passenger by giving limitation of responsibility.

Limitation of the responsibility of the carrier in carrying out flights to passengers is stated in Code No. 1 of 2009 about Aviation namely:

a. The carrier is not responsible and may refuse to transport a sick passenger, unless he can submit a doctor's certificate to the carrier stating that the person is allowed to be transported by airplane.

b. Passenger as referred to in paragraph (1) must be accompanied by a doctor or nurse who is responsible and can assist him during the flight.

c. The carrier is not responsible for losses due to loss or damage to cabin baggage, unless the passenger can prove that the loss is caused by the action of the carrier or the person he employed.

d. The carrier is not responsible for losses suffered by passengers due to late checked baggage, which is caused by forceful conditions, namely natural disasters. 
e. The carrier is responsible for losses suffered due to delays in passenger transportation, baggage, or cargo, unless the carrier can prove that the delay is caused by weather and technical operational factors.

The carrier is indeed responsible for the accident and loss suffered by the passenger caused by the fault of the transporter, but the responsibility of the carrier has its limits in transporting the flight. The author feels that implementation Code No.1 of 2009 it will be difficult for passengers who experience losses due to loss or loss of damage to their baggage, because in point $\mathrm{c}$ it is stated that the Carrier is not responsible for losses due to lost or damaged cabin baggage, except when passengers can prove that the loss is caused by the actions of the carrier or the person he employed. Surely this is an effort that is difficult for passengers on airlines. There needs to be a special body with a neutral position in charge of carrying out inspections related to actions that can harm the passengers.

Examinations related to the completion of accidents and violations in flight are very useful to determine where the errors that resulted in the accident were found so that it was obtained certainty who should take responsibility (Roekasih, 1991: 37). Thus the determination of who bears responsibility is a wise decision and will not harm the innocent party. The relationship between decision-making mechanisms in airlines can be determined or known by two theories, namely the function of the daaderschap and the theory of identification.

Theoretically, the theory of functional actors is applied by judges through three stages. First, which interests are protected by lawmakers in relation to crimes that are threatened by lawmakers. Secondly, which actor is committing a crime, further tracing who is in the position that most determines the occurrence of a crime. In this case the physical offender has turned to functional crime. Third, the question of verification (verification) is asked whether there is sufficient valid proof that a crime is committed by the defendant in relation to the first and second stages. The point is that the actions of the management at the time of committing a criminal act are not in its capacity as a person, but in relation to carrying out its functions and authorities in a corporation, and its actions do not have to do the prohibited acts but also in the form of neglect of obligations.

The civil airline corporation decides or establishes a policy, in which the policy turns out to be deviant or even fatal, namely an accident, in the event that the liability must be viewed carefully who makes or is responsible for the decision and whether its functional duties or authority. If it is stated in the articles of association and household that he acts on behalf of the corporation, then the accident is the responsibility of the corporation, but if it does not, it does the responsibility of the perpetrator personally.

Second is identification theory. Identification theory or direct corporate criminal liability is one of the corporate criminal liability doctrines originating from Anglo Saxon countries, such as Britain and America. This doctrine rests on the assumption that all legal and illegal actions carried out by the high level manager or director are identified as corporate actions. Therefore, this doctrine is used to justify the imposition of criminal liability on corporations, although in reality the corporation is not something that can do itself and cannot have mens rea because it does not have a heart. (Maglie, 2005: 556)

This theory basically recognizes that the actions of certain agents of the corporation, as long as they are related to the corporation, are considered as actions of the corporation itself. In such circumstances, they are not a substitute and therefore, corporate responsibility is not a personal responsibility.

In the theory of identification, people who are identical with the corporation depend on the type and organizational structure of a corporation, but generally include the board of directors, the chief executive officer, or corporate officials or administrators with the same level as the two positions. Because, they are actually synonymous with corporations or if in corporate criminal liability theory states if individuals are given the authority to act and on behalf of and during running a corporate business, mens rea of individuals are also mens rea of corporations.

So it can be concluded that airlines here as corporations that carry transportation services for civil aviation, can be subjected to or held responsible for the damage and loss of aircraft baggage experienced by passengers, based on functional actor theory and identification theory.

\section{CONCLUSION}

Thevery of passenger baggage and or damage suffered by passengers is the responsibility of the airline as a corporation that organizes civil aviation. They are basically responsible for the comfort and security felt by passengers as well as the items they carry during before until after theflight ends. Airlines based on several theories become the party responsible for the loss done by the passenger to the loss of the baggage, even though the perpetrator who committed theft or baggage retrieval is not the airline staff directly but the other party is burdened with the responsibility of handling passenger goods in the baggage, but based on identification theory and functionally, it is enough to attract airlines to their responsibility because of their supervisory authority and other authorities. The omission carried out by airlines over the rampant theft of baggage against passengers is also illegal in the form of intentionally allowing criminal acts even though with its authority the airline can take precautions. Of all these considerations, it is sufficient in this legal scientific writing to conclude that the airline is responsible corporately for theft of the victim's luggage contained in the baggage. 


\section{REFERENCES}

[1] Adnyani, Ni Ketut Sari. Bentuk Perkawinan Matriarki Masyarakat Hindu Bali Ditinjau dari Perspektif Gender dalam Hukum. Jurnal Pandecta. Volume 11. Nomor 1. June 2016. p. 50

[2] Fauzi, Harry. Tanggung Jawab Perusahaan Penerbangan Terhadap Kerugian Barang Bagasi Tercatat Penumpang Pada Penerbangan Domestik (studi pada PT.Garuda Indonesia airlines medan). USU Law Journal, Vol.4.No.2 (March 2016), p. 142

[3] Fuady, Munir. Perbuatan Melawan Hukum, cet.1, (Bandung: Citra Aditya Bakti, 2002), p.3.

[4] Khairandy, Ridwan. Tanggung Jawab pengangkut dan Asuransi Tanggung Jawab Sebagai Instrument Perlindungan Konsumen Angkutan Udara, Jurnal Hukum Bisnis vol 25, Jakarta, 2006, hpp 20-21.

[5] Kizza, Brad. "liability of Air Carrierfor Injuries to Passangers Resulting From Domestic Hijacking and
Related to Incidents", Vol.46 (10 Journal Air law and Commerce 1951Tahun 1980, p..1.

[6] Komar Kanta A, Tanggung Jawab Profesional, ( Jakarta : Ghalia Indonesia, 1994) p..3.

[7] Maglie, Cristina. "Models of Corporate Criminal Liability in Comparative Law", Washington University Global Studies Law Review, (Volume 4: 547, Januari 2005)., p. 556

[8] Nasution, M. N. Manajemen Transportasi. Bogor: Ghalia Indonesia. 2007. p.23

[9] Roekasih E, dan G. Kartasapoetra, Segi-Segi Hukum Dalam Charter dan Asuransi Angkutan Udara, (Penerbit Aramico, Bandung 1991), p 37

[10] Wiradipradja, E. Saefullah, Tanggung Jawab Perusahaan Penerbangan Terhadap Penumpang Menurut Hukum Udara Indonesia, Jakarta: Jurnal Hukum Bisnis Vol 25, 2006

[11] Wirya, Astan. 2015. Kebijakan Formulasi Hukum Pidana Dalam Penanggulangan Tindak Pidana Kehutanan. Jurnal IUS Vol III (7) : 8 